\title{
Technology Transfer and the Promotion of Technical Skills from Japan to Southeast Asia: Case Study of Vietnam
}

\author{
Quynh Huong Nguyen
}

Ritsumeikan University

\begin{abstract}
Technology transfer is regarded as a significant channel by which developing countries can both acquire technologies and develop the workforces. Also, the skill level of employees has been identified in playing a critical role in making technology transfer effective. In the case of Southeast Asia, particularly, Vietnam, Japan is one of the largest investors with large investment capital in high technology industries. However, the lack of a skilled labor force in Vietnam has currently impeded the transfer of technologies from Japan to Vietnam. This paper aims to examine the current situation of technical skill levels of employees in the Vietnamese manufacturing industry as a challenge to technology transfer from Japan to Vietnam through Japanese FDI manufacturing firms. It is suggested in this paper that bridging the huge gap between Japanese technical standards and the Vietnamese workforce's technical skills requires the crucial role of the Vietnamese government.
\end{abstract}

Key words: technology transfer, human resources development, Japan, Vietnam, Southeast Asia, manufacturing industry

\section{Introduction}

Human resource development is one of the important elements for longterm national economic development. A well-equipped labor force will contribute to individual, organizational and national development through improved performance. In Vietnam's case, worker development in general - and technical skill improvement in particular - has become a critical issue, especially in the context that Vietnam has successfully attracted Foreign Direct Investment (FDI), but technology transfer has remained low.
Vietnam ranks as the $14^{\text {th }}$ most populous country in the world and the $3^{\text {rd }}$ in Southeast Asia. Vietnam's population reached over 95.5 million in 2017 (UN, 2017), among which 54.4 million are of working age as noted in the Ministry of Planning and Investment 2016 report. Nevertheless, the percentage of unskilled laborers who have not experienced any technical training in Vietnam is over 80 per cent of the total workforce (MPI, 2016).

It is correct to say that Vietnam is in the "golden population period" in terms of quantity of working-age people but the quality of the labor force is not "golden". The vast majority of the labor 
force in Vietnam does not have experience in any technical training, so the quality of labor remains low and needs to be improved. Especially in the manufacturing industry, the technical skills of laborers are in critical need of improvement.

This paper focused on the manufacturing industry, particularly the fabrication, processing, or preparation of products from raw materials and commodities as the main part of industrialization (Sustainable Development Indicator Group, 1996). In the manufacturing industry, skilled laborers who have abilities and knowledge needed to perform specific tasks (ILO, 2010) play a vital role in operating and maintaining the technology and production.

Manufacturing skilled labor has four level: (i) skill level 1 involves the performance of simple routine physical or manual tasks, which requires physical strength; (ii) skill level 2 involves the performance of tasks such as operating machinery, which requires ability to read instructions; (iii) skill level 3 involves the performance of complex technical and practical tasks, which requires a high level of literacy and numeracy and communication skill; (iv) skill level 4 involves the performance of tasks that require complex problem-solving and decision making skills (ILO, 2012). Based on this classification of skill levels, skills of most Vietnamese workers remain at level 1 and level 2. For a long-term strategy of human resource development and industrialization in Vietnam, the skills of the labor force need to be upgraded to level 3 and level 4 .

In order to upgrade the technical skills of Vietnamese laborers in the manufacturing industry, technology transfer could be promoted through FDI projects and secondly facilitated through educational training programs. In this context, Japan have been traditionally known to be keen on genuinely transferring technologies in order to foster Human Resource Development (HRD) in the host countries (Suematsu, personal interview, 2017). The tradition, philosophy and willingness of Japanese companies in developing human resources of host countries are widely acknowledged and appreciated.

However, technology transfer through FDI and technical skill promotion with benefits for host countries does not happen automatically. The level of technical skills from local labors as well as government intervention are important in ensuring the effectiveness of this technology transfer. Yet, in the case of Vietnam, many have pointed out to the gap between the current level of the Vietnamese workforce's technical skills and Japanese technical standards and requirements as the main impediment to actualize the process of effective technology transfer.

This paper, therefore, aims to examine the current situation of the technical skill level of the Vietnamese workforce as a challenge to technology transfer from Japanese manufacturing 
firms. The main research question of the paper is how the current situation of technical skill level of the Vietnamese workforce has contributed to be a challenge to technology transfer from Japanese manufacturing firms.

This paper is organized in the following order. First, it presents the current situation of technical skills of human resources in Vietnam as well as the current policies of the Vietnamese government in human resource development. Secondly, it examines the challenge of technology transfer from Japan to Vietnam using case study of Vina Mazda. The last part will draw conclusion and offer policy recommendations with respect to human resource development in general, technical skill promotion, in order to benefit from technology transfer.

\section{Conceptual Framework}

The conceptual framework that is presented and used in this research is the Capacity Development Results Framework, or CDRF, or simply The Framework, which is a strategic and results-oriented approach to learning for capacity development. It was introduced by the World Bank in 2009. The Framework is a guide for the planning, implementation and evaluation of capacity building at the national level.

According to the Organization for Economic Co-operation and Development (OECD), capacity is understood as the ability of people, organizations and society to manage their affairs successfully. Capacity development is understood as the process whereby people, organization and society as a whole unleash, strengthen, create, adapt and maintain capacity over time. (World Bank, 2009).

Figure 1. Capacity development as a part of the development process

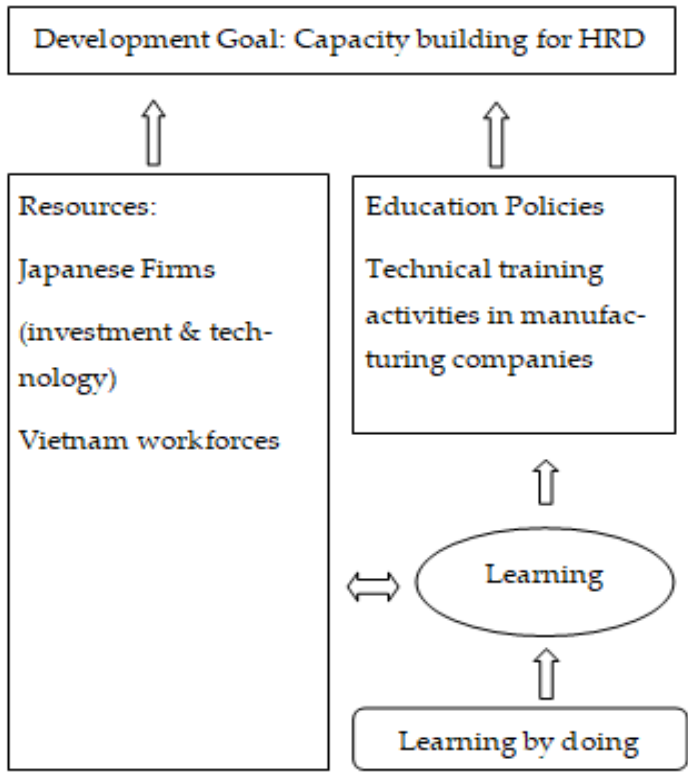

Source: (simplified figure from the World Bank, 2009)

According to the framework for capacity development provided by the World Bank, the development goal is based on resources and local ownership and the effectiveness of resources use. Such types of resources include financial capital, infrastructure, technology, and other endowments. Local ownership consists of the sociopolitical environment, policy instruments, and organization arrangements. However, according to this framework, development goals will be achieved from learning. The learning process, which based on learning activities, will facilitate a change to local ownership and the effectiveness of resource use, those being the sociopolitical 
environment, policy instruments, and organizational arrangements.

For the purpose of this research, the development goal is defined as the capacity building of human resource development, the primary catalyst needed to upgrade technical skills of the Vietnamese labor force in the manufacturing industry. The success of human resource development of Vietnam, as suggested by the above explanation, is reliant upon its domestic human resources and their working relationship with foreign institutions and firms. As such, a well-educated and well-trained domestic labor force through skill transfer from this relationship is vital. The main factor which is affecting the development of learning is the type and quality of learning activities conducted. For this reason, learning by doing is the suggested primary activity in terms of technical transfer from Japanese firms to Vietnamese employees. Summarized in a model, a successful or smooth learning process or technology transfer from Japanese company to Vietnamese labor will be as follow:

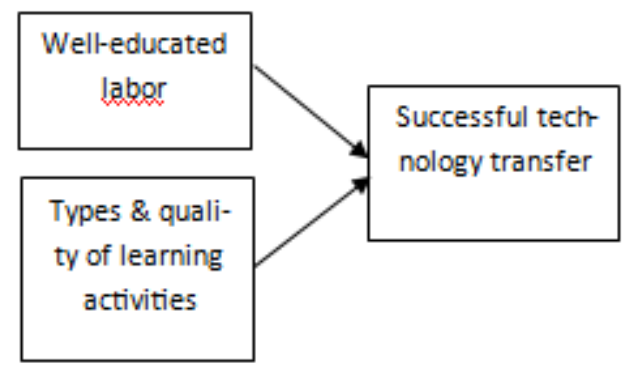

Based on this model, this paper argues that the lack of well-educated labor in Vietnam and the huge gap between this labor skill to the required standard has become a challenge in technology transfer by the Japanese firms. As a consequence, the type and quality of learning activities both by Japanese firms and the government are central in determining the success of this technology transfer.

\section{Methodology}

The problem of technology transfer is a practical issue but at the same time a complex issue which might not be similar between one company and another. In addition to explaining the current situation on technical level skills of Vietnamese labors in general, this paper, therefore, also uses a case study to better capture and approach the problem rather than discussing it at theoretical level. While each case might be unique, this case study is expected to help illuminate the case in real situation. The selection of the collaboration between Mazda Motor Corporation Japan and Vina Mazda - Thaco Group as one of the major companies in Vietnam is also expected to represent other companies with shared characteristics. As a partner, Vina Mazda cooperates with Mazda Japan in terms of transferring technical skills in the automotive industry to Vietnamese employees through on-the-spot workshops with Japanese experts and have been reported to demonstrate a case where learning by doing is the main factor which drives the capacity building of the firm.

Data collection for this paper is conducted through observation of the activities of Thai-Nichi Institute of Technology as well as interviews with Dr. Phan Tiem, the principle of Vocational 
School of Thaco Group and Phan Quynh Trung, Director of Technical Division, Vina Mazda. In addition, this paper also conducts many in-depth interviews with Japanese organizations such as Japan External Trade Organization (JETRO) Hanoi, JETRO Ho Chi Minh, JETRO Bangkok, JICA Bangkok, and Denso International Asia Bangkok. These interviews were conducted in order to get additional information not found in the previous literature.

\section{The Current Status of the Technical Skills of the Vietnamese Workforce in the}

\section{Manufacturing Industry}

According to the General Office for Population Family Planning of Vietnam, the advantage of Vietnam is its human resource, which reached 63 million people, the working age population, in 2018 (The Ministry of Labor-Invalids and Social Affairs, 2018). This potential source of labor is attracting many foreign direct investments to Vietnam. However, the disadvantage of Vietnamese labor is the shortage of technical skills. The number if high skilled labor in Vietnam is smaller than other countries in Southeast Asia. As reported by The Global Human Capital report 2017, the high-skilled labor occupies $10 \%$ in Vietnam, $14 \%$ in Thailand and $25 \%$ in Malaysia (WEF, 2017).

According to the Report of Labour of Vietnam in 2017, the percentage of labor force with technical qualification is $21,5 \%$ of the total labor force (General Statictis Office of Vietnam, 2017). This low percentage demonstrates the disadvantage of the Vietnamese labor force as it means most of the Vietnam labor is lacking technological skills. They are grouped as workforces that can only work in simple job such as assembly work and cannot utilize the high- technology from foreign firms.

Besides, the number of graduated students from higher education is small, about $21,5 \%$ of the labor force (General Statictis Office of Vietnam, 2017). These numbers reflect the lack of engineers who can work in sophisticated works or research and development projects. The lacking number of skilled workers and engineers presents the quality of human resources of Vietnam in manufacturing industry.

According to Mr. Yusuke Taguchi, Deputy Representative, AMEICC Secretariat, AEM-METI Economic and Industrial Cooperation Committee, Japanese manufacturing firms want to build up technical skills for employees, but there is a huge gap between Japanese technical standards and the current local technical level, which keeps preventing the transfer of the technical skills to local workforce (Yusuke Taguchi, personal interview, 2016). In order to take advantage of golden population structure and bridge the gap of technical levels, Vietnamese government should play a crucial role.

The current policies and strategies of the

Vietnamese government in promoting technical skills of human resources

The Vietnam policy framework for long-term HRD is defined and guided by 
the key government strategies and plans, including the Socio-Economic Development Plan 2011-2020 and The Human Resources Development Strategy 2011-2020. This Plan focuses on restructuring and reforming the education and training system while addressing various challenges as could be seen on Table 1 and Table 2.

Table 1. Targets of the HRD strategy 2011-2020

\begin{tabular}{|c|c|c|}
\hline Targets & 2015 & 2020 \\
\hline $\begin{array}{l}\text { Rate of trained laborers } \\
(\%)\end{array}$ & 55 & 70 \\
\hline $\begin{array}{l}\text { Rate of Vocationally } \\
\text { trained laborers }(\%)\end{array}$ & 40 & 55 \\
\hline $\begin{array}{l}\text { State management, policy } \\
\text { making and international } \\
\text { law }\end{array}$ & 18,000 & 20,000 \\
\hline $\begin{array}{l}\text { University and college } \\
\text { lecturers }\end{array}$ & 100,000 & 160,000 \\
\hline Science-technology & 60,000 & 100,000 \\
\hline Medicine, health care & 70,000 & 80,000 \\
\hline Finance - banking & 100,000 & 120,000 \\
\hline Information technology & 350,000 & 550,000 \\
\hline
\end{tabular}

Table 2. Actual figure of the targets of the HRD strategy 2011-2020

\begin{tabular}{ll}
\hline \multicolumn{1}{c}{ Actual figure } & $\mathbf{2 0 1 7}$ \\
\hline Rate of trained laborers (\%) & 53 \\
$\begin{array}{l}\text { Rate of Vocationally trained } \\
\text { laborers (\%) }\end{array}$ & 19,9 \\
State management, policy & 18,000 \\
making and international law & \\
University and college lecturers & 72,792 \\
Science-technology & 43,849 \\
\hline $\begin{array}{c}\text { Sources: Ministry of Labor- Invalids and Social } \\
\text { Affairs }\end{array}$
\end{tabular}

These two table list the challenges in human development by the Vietnamese government, highlighting the gap between the intended development rate and the actual achievement this program has made. The table indicates that Vietnam human resources is apparently still lacking trained laborers and vocationally trained laborers despite of this government policy. In the strategy, for example, the targeted percentage of trained laborers are $55 \%$ in 2015. However, the actual percent of trained workers in 2017 are $53 \%$, or less than the targeted percentage which supposed to be increasing to reach $70 \%$ in 2020 . This has not mentioned other targets which also do not met the targeted goals. As the theoretical framework used in this paper suggested, these workforces need to be promoted by learning activities such as vocational and education training system of Vietnam and through technical training in Japanese firms.

In regards to the focus of this paper on manufacturing industry, the strategies on the development of human resources during 2011-2020 period do not provide detailed action plans especially in the manufacturing industry. Technical skill promotion is an important part of human resource development because it relates to the process of industrialization and modernization which drives the country to a higher level of long-term development. The Decision No. 579/QĐTTg is still a general plan without priorities and specific policies for implementation in order to develop the quantity and quality of skilled labor. 
Among ASEAN countries, Vietnam is lagging behind Thailand in terms of policy measures and directions for human resource development adopted by the government. In the case of Thailand, the government has promoted human resource development with five Action Plans: (i) The Vocational Education Act 2008, (ii) The Skills Development Promotion Act 2002, (iii) The National Science, Technology and Innovation (STI) Policy and Plan 2012-2021, (iv) The National Education Act of 1999, and (v) The $11^{\text {th }}$ National Economic and Social Development Plan (2012-2016) (UNCTAD, 2015). These Action Plans are being implemented at all levels of education and the government has finances to support STI teaching and training, provided research scholarships and promoting cooperative education. (UNCTAD, 2015). Furthermore, the Thai government has cooperated with the Japanese government in many human resource development programs with assistance from JICA initiated by a project of King Mongkut's Institute of Technology Ladkrabang and have been implemented since 1971, which has resulted in a pool of high-quality engineers and scholars for the industrialization process in Thailand (Katsuya Miyoshi, personal interview, 2017). Meanwhile, the Vietnamese government has not yet promoted any detailed action plans for effectively actualizing the general strategy of human resource development.

\section{Technology Transfer to Vietnamese workforce by Japanese firms}

Technology transfer through FDI projects is one of the channels to upgrade technical skills for human resources since employees have to adapt to new technology, new machinery, and new management.

Japanese companies have always made their intention clear in promoting the technical level of human resources in host countries through the process of technology transfer (Suematsu, personal interview, 2017). The transfer of technologies to a country has been undertaken by the Japanese firms investing in the country. Japanese companies frequently train local employees from the beginning and provide on-the-job training so that employees can learn technical know-how. Furthermore, not only Japanese firms but also Japanese organizations have held many programs facilitating the process of technology transfer programs in Vietnam.

On-the-job training or learning by doing in Japanese firms is the training which the employee will take part in in the workplace and it taught technical skills by seniors or experts. The employee will enhance the skills by learning on the spot or learning by doing. For example, in Denso International Asia in Thailand, new employee is paired with a senior employee so that the new employees can learn know-how by working in the factory (Suematsu, personal interview, 2017). Onthe-job training programs are often organized in the workshop for the workers and technicians. 
Based on the research conducted in this study, the two major challenges facing Japanese firms in Vietnam is the technical gap of employee and job hopping (Sato Susumu, personal interview, 2017). There are several reasons for the job-hopping phenomenon in Vietnam. Firstly, there is a different working culture compared Japan with where the employees stay with the same company for their entire life. Vietnamese employees want to gain experience in order to get a higher-paid job from other companies. Secondly, in general, Japanese companies have not yet offered higher positions level for foreigner employees therefore encouraging Vietnamese skilled employees to move to another company if they can get a higher position (Dao Trong Hieu, personal interview, 2017).

In fact, it usually takes a lot of time and money invested by the Japanese firms in order to bridge the gap of technical skills by providing new employees with on-the-job training programs. However, workers, once they are trained and equipped with a certain level of technical skills, do not commit themselves to the companies but want to move to any other firms that pay a them higher wage. Japanese firms then must restart the process of recruitment and training which is very costly. The job-hopping problem has also made the technology transfer process distracted and less efficient because firms must repeatedly provide technical training for new comers, then they are constrained to advance the technology transfer to the higher levels.

\section{Case study of Vina Mazda}

In the process of knowledge and technology transfer to local employees, Japanese firms' training systems have mainly been based on the form of on-thejob training or learning by doing. Employees are supposed to acquire essential technical knowledge and skills in the workplace where the seniors provide verbal instructions rather than written materials. When Japanese investors started establishing factories in Vietnam, they set up such a system, in which Vietnamese senior workers give guidance to junior ones, in order to improve practical and technical skills for the Vietnamese workers.

The paper presents Vina Mazda Thaco Group as a case study of technology transfer from Mazda of Japan to Vina Mazda of Vietnam because Vina Maza is the only private Vietnamese company that assembles and produces Japanese cars and receives technology from Japan in the automotive industry.

As a short introduction, Thaco Truong Hai Auto Corporation Ltd. was established on April 29, 1997.Thaco Group is Vietnamese company that produces and assembles passenger cars with the localization rate of 15-40 per cent (Thaco Auto, 2016). From the beginning, Thaco Group assembled automobile spare parts imported, and now the company is establishing its own value chain, taking the roles as a supplier, a manufacturer, a distributor, and a retailer. The main business to manufacture and assemble of Thaco Group are the passenger vehicles of 
KIA (Korea), Mazda (Japan), and Peugeot (France).

Mazda, Japanese auto brands, had arrived at Vietnam in late 2010 through its manufacturer and distributor Vina Mazda - a subsidiary of Truong Hai Auto Corporation (Thaco). After 8 years of operation in Vietnam, Vina Mazda achieved sales of 80.000 units; Vina Mazda is getting popular as a leading auto brand in Vietnam. (Thaco Auto, 2016).

Vina Mazda manufacturing and assembly factory was built with the maximum capacity of 10,000 vehicles per year. All spare parts in the manufacturing process in Vina Mazda factory are imported from Japan with a process controlled by Mazda's experts. In addition, Vina Mazda and Mazda signed contract of sharing important technology production line with high investment cost such as electrostatic painting or spraying and fire-retardant paint production lines, test-drive road, etc.

The technology transfer from Mazda trainers from Japan to Vina Mazda's Vietnamese engineers has been conducted based on learning by doing activities through many steps. Mazda sends Japanese engineers to Vietnam to work with Vina Mazda's engineers on Mazda's technology. Depending on the process of transferring technology and know-how to Vietnamese engineers, Japanese trainers must stay in Vietnam from 6 to 8 months. There are 5 steps in the process of technology transfer from Japanese trainers to Vietnamese engineers: (1) Vietnamese engineers read and understand the technology guidelines; (2) Vietnamese engineers read and understand the technology guidelines and practice the work; (3) Vietnamese engineers don't read the technology guidelines and do the job $50 \%$; (4) Vietnamese engineers don't read the technology guidance and do the job $70 \%$; (5) Vietnamese engineers don't read the technology guidelines and do the job $100 \%$. When the Vietnamese engineers can carry out the work successfully without reading the guidelines, the technical transfer is completed.

After participating in the technical training courses by Mazda's Japanese trainers, Vietnamese engineers then train Vietnamese workers at the workplace and Japanese trainers from Mazda become examiners. The exam for Vietnamese workers tested on the workshop and on paper (100 multiple - choice questions). When the trainers of Mazda return to Japan, Vietnamese engineers play the role of examiners.

The technology transfer can be upgraded only when Thaco Group make a request to Mazda. In order to prepare for a promotion of technology transfer, Thaco Group must prepare all the fees and technical preparation for trainers from Mazda. The fees include allowances to trainers from Mazda at the rate of 800 USD per hour and the accommodation fee. The technical training duration is $2-2.5$ months. The acceptance by Mazda depends on the technology which Thaco Group requests to be transferred and the demand of Vietnamese market (in case of increasing local content). Currently, the 
process of technology transfer from Mazda to Thaco Group is going well. In March 2017, Thaco Group started building a new plant for Vina Mazda automotive factory with the capacity of 100,000 cars per year and new technology from Mazda of which robots' control $70 \%$ of the assembling work. Besides, the testing line will be equipped with modern technology facilities connected to the global technical information system of Mazda (Nguyen, personal interview, 2017).

\section{Challenges in technical know-how transfer in case of Vina Mazda}

Based on the research, the process of transferring technology from the Mazda firm to the Thaco Group has encountered some difficulties in terms of upgrading the technical skills for employees and promoting local content for Thaco Group. The finding of this research shows that among the two most significant challenges are as follows.

Firstly, language has become one of the main challenges in communication between Vietnamese engineers and Japanese trainers. The Japanese trainers usually speak Japanese so there is a language is the problem for the Vietnamese engineers. Although there is some senior Japanese employee that can speak English, the majority of training activities are given in Japanese because they cannot speak English very well.

In addition, the technical guidelines are also written in Japanese, so the Vietnamese staff must study Japanese. Thaco Group is in Quang Nam Province, in central Vietnam. The industrial zone is a hundred kilometers away from the city, and it is not an attractive working place for those who can speak both Japanese and English. Currently, the Thaco Group staff has offered free Japanese courses after office hours in the evening, but the courses are not so effective since employees are already tired after a full working day. It may be more effective if the Thaco Group organize Japanese language courses at least 3 months prior to the technical training time so that the employees can get familiar with the technical vocabulary in Japanese and it may help the technical training from Japanese trainers to be more effective.

Secondly, the technology transfer depends on Mazda in Japan; the Thaco Group can only upgrade technology if the market for Mazda cars. This is really a big challenge for Vina Mazda because the Vietnamese government has not encouraged a bigger automotive market yet.

\section{Conclusion}

Human resource development with regards to the promotion of technical skills in the Vietnamese manufacturing industry has been facing many challenges which related to technology transfer from Japan to Vietnam through Japanese manufacturing firms. Echoing to the proposed hypothesis, this paper found that the lack of Vietnamese labor skill has become one of the challenges in technology transfer from Japanese firms. While the firms have initiated learning activities as also apparent in the case of 
Vina Mazda, there are also challenges to maximize the quality of this learning activities.

The paper, therefore, recommends that the Vietnamese government also take part in filling this gap in order to ensure a successful technology transfer and broadly human development in Vietnam. In this respect, the Vietnamese government is supposed to enable and support the cooperation between firms and universities. Moreover, the Vietnamese government should listen to the investors in order to provide more relevant policies on technology transfer. In addition, the government of Vietnam should establish national institutions for $R \& D$ in advanced technologies which could create s pool of high-level engineers which ready to supply the manufacturing industry.

\section{Educational policies}

First, in order to make the human resource development strategies effective in enhancing technical skills, the Vietnamese government should develop detailed action plans not only for vocational training activities, but also for strengthening university and institutes of higher education for sophisticated R\&D activities. Moreover, the government should provide a budget for R\&D activities in universities. According to NASATI (2014), the budget for R\&D activities from the Vietnamese government to the universities is just about 5 per cent of the total government budget for R\&D activities. Universities should be the places which provide most engineers and technical personnel to the industrial sector for technical advancement of the country. The $R \& D$ budget for universities should be increased for use in new laboratories, equipment, scientific books, and training programs for students.

Secondly, Japanese language is very important in training process in Japanese manufacturing firms. The educational policies should not only promote the technical skills but also the language should be enhanced.

Thirdly, the government should establish national engineering sectors for the promotion of high - tech manufacturing industries, which may provide sophistication of basic technologies to be applied in many sectors of industry. Moreover, the government can become the coordinator connecting firms and universities. The collaboration may include lessons, projects on training, scientific research, and technology transfer between the manufacturing firms and universities. Such cooperation has proved to be effective in other countries. For example, in Thailand, the Thai-Nichi Institute of Technology (TNI), established in 2005 by the Thai-Japanese Technology Promotion Institute, provides education at undergraduate and graduate levels in engineering, information technology, business administration and language skills with the programs combining academic teaching and practical training in Japanese companies which based in Thailand. The Monozukuri program is a program for third-year students of 
engineering studies which consists of many Japanese manufacturing plant tours for TNI students and lecturers. The Japanese government strengthens the connection between TNI and Japanese manufacturing firms through joint research and the sharing of technology.

\section{Industrial policies}

Firstly, the promotion of technical skills for HRD in Vietnam is closely related to foreign firms in general, and to Japanese manufacturing firms. The government should listen to the Japanese firms and consider the challenges which they are facing while they invest in Vietnam. For example, according to one Japanese firm, Vietnam's tax system for foreign investment companies has not been stable, thus, some Japanese firms intend to invest in Vietnam only for a short period of time (Sato Susumu, personal interview, 2017). The Vietnamese government should consider providing consistent tax policies for foreign investment companies.

Secondly, the Vietnamese government should introduce concrete policy measures to promote supporting industries, including the automotive industry in cooperation with potential Japanese firms to expand the production.

\section{About the Author}

Quynh Huong Nguyen is currently a Ph.D candidate at the Graduate School of International Relations, Ritsumeikan University. She obtained her BA in Orientals Studies from Vietnam National University and MA in International
Relations from Gadjah Mada University. She has strong interested in socialeconomic development in Southeast Asia. She also researches on the policy making of individual ASEAN's countries as well as foreign policy between both countries and group of countries.

\section{References}

General Statictis Office of Vietnam, G. (2017). Labour in Vietnm 2017. Ha Noi: General Statictis Office of Vietnam. International Labor Office (ILO). (2010). A skilled workforce for strong, sustainable and balanced growth. Geneva: International Labor Office.

International Labor Office (ILO). (2012). International Standard Classification of Occupations, ISCO-08. Geneva: International Labor Office.

Ministry of Planning and Investment of Vietnam (MPI). (2016). Report: Labor and Employment of Vietnam in 2016. Hanoi: General Statistics Office of Vietnam.

Mankiw, N. G. (2016). Macro Economics. New York: Worth Publishers.

Nguyen, H. M. (2016), Situation, orientation and solutions to develop vocational training to meet the labor demand of industrial parks (In Vietnamese, online version), accessed on June 2, 2016, available at the portal of General Directorate of Vocational Training, Ministry of Labor, Invalids and Social Affairs of Vietnam http://en.tcdn.gov.vn/. 
Organization for Economic Co-operation and Development (OECD). (2013). OECD Reviews of Innovation Policy: Innovation in Southeast Asia.

Rasiah, R. \& Sadoi, Y. (2012). Innovation and industrialization in Asia. London, Routledge.

Sustainable Development Indicator Group. (1996). Working Draft Framework, Version 2, June 1996.

Thaco Auto Corporation. (2016). Annual Report 2016. Thaco Auto Corporation.

United Nations (UN), Department of Economic and Social Affairs/Population Division. (2017). World Population Prospects: The 2017 Revision. New York: United Nations.

United Nations Conference on Trade and Development (UNTACD). (2015). Science, Technology and Innovation Policy Review of Thailand. United Nations.

United Nations. (2017). World Population Prospects: The 2017 Revision. New York: United Nations.

Vietnam, Decision No. 879/QD-TTg dated June 9, 2014 signed by Prime Minister Nguyen Tan Dung approving the Industrial Development Strategy through 2025, vision toward 2035, Hanoi: Government Portal, Socialist Republic of Vietnam. Retrieved from http://www.chinhphu.vn/portal/pa ge/portal/English.

Vietnam National Agency of Science and Technology Information (NASATI). (2014). The report on Scientific Research and Technology development in 2014.

World Bank. (2009). The Capacity Development Results Framework. New York: The World Bank Intitutes.

World Econimic Forum. (2017). The Global Human Capital Report 2017. Geneva: World Economic Forum 